\title{
Superlucros: a prova empírica do exclusivo colonial
}

\author{
José Jobson de Andrade Arruda*
}

\section{RESUMO}

Este texto é uma réplica ao artigo "Exclusivo metropolitano, 'superlucros' e acumulação primitiva na Europa pré-industrial”, de André Arruda Villela, publicado no número 23 desta revista, no qual critica o modelo de antigo sistema colonial, sobretudo as noções de monopólio e superlucros, recusando qualquer tipo de contribuição da exploração colonial para o deslanchar da Revolução Industrial britânica. Essencialmente, confirmo a validade dos índices por mim aferidos sobre os ganhos de monopólio no livro O Brasil no comércio colonial, publicado em 1980; reafirmo a contribuição estratégica do mundo atlântico colonial para o arranque da industrialização realizada, a britânica, e das industrializaçôes frustradas, casos franco-português.

Palavras-chave: história econômica; sistema colonial; monopólio; superlucros; industrialização.

\section{ABSTRACT}

This article responds to André Arruda Villela's paper "Exclusivo metropolitano, 'superlucros' e acumulação primitiva na Europa pré-industrial", published in the issue 23 of this journal. Villela's paper criticizes the colonial system model, especially the notions of monopoly and superprofits, denying any contribution of colonial exploitation to the launch of the British Industrial Revolution. Essentially, I restate the validity of the figures I verified in my book O Brasil no comércio colonial, published in 1980; I reiterate the strategic role of the Atlantic colonial world for the outset of the effective Industrial Revolution in Britain, as well as for the failed industrialization of France and Portugal.

Keywords: economic history; colonial system; monopoly; superprofits; industrialization.

Opinião - DOI - http://dx.doi.org/10.1590/2237-101X015029018

Artigo recebido em 6 de junho de 2014 e aprovado para publicação em 12 de julho de 2014.

* Doutor pela Universidade de São Paulo (USP) e professor sênior da mesma universidade. São Paulo, SP,

Brasil. E-mail: jobson.a@uol.com.br. 
Este texto não é uma réplica. É um convite ao diálogo endereçado aos historiadores de boa vontade. Refere-se ao combativo artigo de André Arruda Villela, "Exclusivo metropolitano, 'superlucros' e acumulação primitiva na Europa pré-industrial”, publicado nesta mesma revista no segundo semestre de 2011. ${ }^{1}$ Essencialmente dirigido contra o modelo de antigo sistema colonial elaborado por Fernando Novais, questiona os três eixos principais que conformam sua arquitetura: exclusivo metropolitano; expropriação de excedentes coloniais via superlucros; e impacto do excedente colonial sobre a industrialização britânica, antecipando no preâmbulo que considera esta composição interpretativa um "modelo essencialmente axiomático", com "limitada aderência tanto à teoria econômica quanto à evidência empírica". 2

Conclui, por antecipação, que o exclusivo náo era absoluto, pois numerosas brechas o desfiguravam; que não havia superlucros capazes de dar sustentação à extração avultada de excedentes; e que era improvável a conexão entre esses recursos e o deslanchar da revolução industrial na Europa. ${ }^{3}$ Tudo isso por conta da escassez, ou mesmo falta, de evidências empíricas sólidas que o comprovassem.

Independentemente de concordarmos ou não com tais assertivas, é justo reconhecer a qualidade do texto, o esforço argumentativo e a ampla literatura histórica mobilizada, seja dos textos produzidos pelos economistas historiadores europeus e norte-americanos na vertente da New Economic History e ao abrigo da economia clássica, bem como da copiosa produção dos historiadores ditos "intérpretes alternativos" — grupo sediado majoritariamente na UFRJ —, do qual ele se faz, neste artigo, uma espécie de porta-voz.

Não me aprofundarei na discussão sobre o monopólio em si. Simplesmente direi que desqualificá-lo como conceito válido para interpretar a economia colonial pela simples constatação de que havia concorrência entre os mercadores metropolitanos e pelas possibilidades de os senhores de engenho, através das Câmaras, atuarem na definição dos preços das mercadorias coloniais ${ }^{5}$ é insuficiente. Isso porque a prática do exclusivo não implicava a desapariçáo completa da concorrência interimperial que, naturalmente, redundava em brechas no regime de exclusivo, concretizadas em açóes militares ou corsárias, arribadas forçadas ou concessôes de licenças especiais que, em determinadas conjunturas litigiosas, tendiam a se multiplicar em benefício dos aliados de ocasiáo; nem mesmo das efetivas negociaçóes entre os colonos e a coroa. Ainda mais porque a aceitação desses pressupostos exigiria uma sustentaçấo empírica do mesmo nível da que fiz sobre o ganho de monopólio, o que não se verifica no texto, pois as evidências apresentadas se resumem a exemplos esporádicos e, portanto, insatisfatórios.

\footnotetext{
${ }^{1}$ VILLELA, André Arruda. Exclusivo metropolitano, superlucros e acumulação primitiva na Europa pré-industrial. Topoi, v. 12, n. 23, p. 4-29, jul./dez. 2011.

${ }^{2}$ Ibid, p. 4.

${ }^{3}$ Ibid, p. 16.

${ }^{4}$ Ibid, p. 17.

${ }^{5}$ Ibid, p. 5 e ss.
} 
Reservo-me para a discussáo em que sou diretamente chamado a intervir. Identificado como correligionário da noção de antigo sistema colonial, sou envolvido especificamente na severa crítica ao procedimento metodológico referente ao quesito "superlucros". Constatei com satisfação, porém, que talvez tenha sido esta a primeira vez que fui convocado à ribalta quando se trata de questionar o antigo sistema colonial, sob cuja inspiração escrevi meus primeiros trabalhos. Paradigma interpretativo valioso com o qual não tenho hoje o mesmo grau de aderência, como os artigos produzidos na última década vieram a demonstrar; ${ }^{6} \mathrm{e}$ que o texto em vias de publicação, "O moderno sistema colonial", certamente referendará. De qualquer forma, apraz-me sobremodo ver num texto de viés incisivamente crítico o reconhecimento que André Villela faz da tese em apreço, O Brasil no comércio colonial, ${ }^{7}$ ao qual se refere como sendo um "importante estudo" (...) "um dos raros esforços (possivelmente, o único) de mensuração dos lucros obtidos no comércio colonial português com o Brasil". ${ }^{8}$ Estudo que, diga-se de passagem, foi escrito há quatro décadas, um exercício pesado de quantificação realizado sem o respaldo das modernas tecnologias de informação. Texto tratado com respeito por nosso crítico, uma sinalizaçáa positiva do necessário diálogo intelectual infelizmente travado nos últimos tempos entre as duas principais comunidades de historiadores brasileiros, paulistas e fluminenses, sobretudo no campo específico da produçáo histórica relativa ao período colonial.

A civilidade acadêmica exige resposta aos questionamentos. É parte dos bons costumes. Observa-se no texto em apreço, preliminarmente, que a erudita argumentaçáo lastreia-se fundamentalmente nos textos dos economistas historiadores que, por vezo de ofício, tendem a forçar a teoria sobre a história, empilhando por décadas argumentos que relativizam, ou simplesmente recusam, o papel exercido pelo mundo colonial no desenvolvimento econômico da Europa. Por certo, uma espécie de catarse, de purgaçáo do sentimento de culpa entranhado na consciência europeia, cujo significado último é: nada devemos porque nunca exploramos.

Sua argumentação de base carece exatamente do que acusa faltar nas posiçôes de seus contrários: a comprovação empírica. Tanto que a forma assertiva da argumentação posta na problematização não se reproduz nas conclusôes. Escreve Vilella: "Há muitos indícios de que os excedentes extraídos de tal relação [exclusivo] não foram particularmente extraordinários, sendo provavelmente errada a noção de que a exploração colonial teria proporcionado 'superlucros"'. A utilização dos vocábulos indícios e provavelmente revelam insegurança. Esperavam-se, em função das proposiçôes contundentes, conclusôes categóricas que não dei-

\footnotetext{
${ }^{6}$ Refiro-me, mais especificamente, ao artigo ARRUDA, José Jobson de Andrade. Decadência ou crise do império luso-brasileiro: o novo padrão de colonização do século XVIII. Revista USP, p. 66-79, jun./ago. 2000. ${ }_{7}^{7}$ ARRUDA, José Jobson de Andrade. O Brasil no comércio colonial. Sáo Paulo: Ática, 1980. Tese de doutoramento escrita em 1972 e defendida em 1973.

${ }^{8}$ VILELLA, André Arruda, op. cit., p. 8.

${ }^{9}$ Ibid, p. 15 . Grifo nosso.
} 
xassem margem a qualquer dúvida. Contraditoriamente, para proposiçóes rascantes temos conclusôes amenas. Delas resulta apenas um campo hipotético aberto às futuras pesquisas, ou seja, estamos nesta matéria como estávamos há meio século.

A mesma hesitação se dá na abordagem da relação entre a transferência de recursos coloniais e a industrialização inglesa, uma possibilidade que "deve ser vista com reservas" ${ }^{10}$ Reservas é uma expressão tímida face à dureza da proposição. Reservas não são certeza absoluta. Há uma possibilidade de que a afirmação que se quer negar seja verdadeira. Afinal, o que se póe no lugar da interpretaçáo arquitetada pelos aderentes ao modelo de sistema colonial? Pouco. Ilações retóricas alicerçadas em indícios pontuais referidas a experiências históricas alheias vazadas em exercícios contrafactuais que, por via da dedução lógica, convertem-se em prova empírica e verdade histórica. Filigranas. Náo uma constelaçấo substancial de argumentos empiricamente sustentados. Assim mesmo, arroga-se o direito de acoimar de "raciocínio falacioso" ${ }^{11}$ o constructo dos seus contrários, apodando-o de "axiomático". ${ }^{12} \mathrm{Se}$ falacioso no caso significar sofisma, é passável, mas se for indicativo de falsidade como o discurso deixa entrever, é excessivo, pois ultrapassa os limites da boa convivência acadêmica, travando o diálogo.

A quem cabe o ônus da prova? A quem acredita nos superlucros e exibe as provas, como o fizemos, mesmo que se constituam em provas indiretas, mesmo que incompletas, ou aqueles que deles simplesmente o colocam sob suspeição? Penso que cabe aos "alternativos" provar empiricamente a existência de lucros reduzidos no comércio colonial. Mas Vilella pensa o contrário, pois chega a concitar, no final do artigo, os defensores do "esquema" Novais a se esforçarem para "dotá-lo de sustentação mais robusta", pois afinal, reitera, "porque [sic] o ônus da prova [empírica] deva recair apenas sobre as interpretaçôes alternativas". ${ }^{13}$ É irônico.

Afinal, qual é o busílis da questão? Mais do que a existência ou não de superlucros, é a metodologia utilizada para determinar a formação de preços que está em pauta. Aí se aloja o nó do problema. André afirma corretamente que sobrepreço não é equivalente à taxa de lucros do comércio colonial, pois se trata de uma "medida de margem bruta de comercializaçáo que serve para cobrir todos os custos do empresário" e não somente para a "compra e transporte da mercadoria". ${ }^{14}$ Perfeito. Se náo estivessem incluídas contabilmente todas as despesas requeridas por Villela, próprias ou não, tais como despesas de capital, eventuais direitos de monopólio, gastos com pessoal, pagamento de comissão a agentes, os resultados ficariam deformados e os índices alcançados nada significariam. Mas erra ao afirmar que nos meus cálculos entraram apenas as receitas obtidas com a venda dos produtos em Portugal, "deduzidas dos gastos com a compra das mercadorias nos portos brasileiros (acrescidos de despesas de fretes

\footnotetext{
${ }^{10}$ Ibid, p. 15. Grifo nosso.

${ }^{11}$ Ibid, p. 15. Grifo nosso.

${ }^{12}$ Ibid, p. 4.

${ }^{13}$ Ibid, p. 17.

${ }^{14}$ Ibid, p. 8. Grifo nosso.
} 
e comissóes)". ${ }^{15}$ Pois, cônscio das limitaçóes que meu procedimento poderia encerrar, remeto ao livro de Adrian Balbi, que alarga o escopo das despesas incluindo as comissóes latu sensu, inclusive dos agentes, e "outras despesas até o embarque", bem como os direitos de saída nos portos de origem, no caso dos produtos de importação, isto é, da exportação colonial. ${ }^{16}$ As ditas despesas de capital reclamadas são relativas. Se as mercadorias são transportadas nas embarcaçôes dos próprios negociantes, as despesas de capital serão recompensadas em parte pelo valor do frete recebido; se não possuir embarcaçôes despenderá o custo do frete, mas também náo terá as tais despesas de capital fixo reclamadas, somente de pessoal ou para a remuneração de empréstimos destinados a compor o capital de giro da operação.

Mais importante ainda é reter que os mercadores de grosso trato que operavam no comércio marítimo de longa distância desconheciam a especialização. Eram, a um só tempo, negociantes, armadores, financistas, banqueiros, prestamistas, rentistas, seguradores, e, excepcionalmente, empresários industriais e agrícolas, pois tinham enorme resistência em adentrar o universo da produção, mantendo-se permanentemente alertas para as melhores oportunidades oferecidas pelo mercado. De resto, extremamente volátil por sua própria natureza e que, por isso mesmo obrigava à diversificação das aplicaçóes em matérias-primas, alimentos, mineração, moedas, armazéns, navios, como forma de proteção contra as frequentes perdas setoriais. Em suas operaçôes, o capital fixo jogava um papel relativamente pequeno, pois a parcela maior da riqueza era constituída pelo capital circulante que buscava a liquidez mais imediata possível, ${ }^{17}$ volubilidade intrínseca que era a marca distintiva do capital mercantil expressa na agilização do seu circuito operaciona ${ }^{18}$ cuja finalidade era a realização mais imediata possível do capital dinheiro. Daí a complexidade das formas assumidas pela acumulação e, por desdobramento, dos modos de apropriação dos excedentes auferidos na empresa colonial, que não podem ser reduzidas a uma operaçáo simples de ganho de monopólio, ou de margem, pois esta é apenas uma das ferramentas da expropriação que tem que ser pensada em sua dimensão macro, em sua dimensão sistêmica.

Senão, vejamos. Perdas por perecividade não afetam uniformemente todos os produtos transacionados e, por conseguinte, não pode entrar genericamente na pauta dos custos. Se afetam o comércio do açúcar, exigindo uma logística adequada para sua alocação no mercado europeu de modo a reduzir o máximo possível as perdas, o mesmo não se dava em relação ao tabaco, couros, pau-brasil e a grande maioria dos produtos coloniais exportados. Não se podendo, portanto, incluir este custo específico e ocasional em todos os preços como

\footnotetext{
${ }^{15}$ Ibid, p. 8.

${ }^{16}$ BALBI, Adriano. Essai Statistique sur le Royaume de Portugal et l'Algarve, Comparé aux autres États de l'Europe. Paris: Chez Rey et Gravier, 1822. p. 431.

${ }^{17}$ BRAUDEL, Fernand. Civilização material, economia e capitalismo. São Paulo: Martins Fontes, 1966. v. 2. O Jogo das Trocas, p. 201 e ss.

${ }^{18}$ ARRUDA, José Jobson de Andrade. Comércio colonial e exclusivo metropolitano. In: SZMRECSÁNYI, Tamás (Org.). História econômica do periodo colonial. São Paulo: Hucitec, 1996. p. 220.
} 
propóe nosso crítico. O mesmo se pode dizer dos direitos de monopólio pagos pelos contratadores dos estancos reais, cujo desembolso se fazia de uma só vez no ano do arremate sobre os produtos estancados, caso do pau-brasil, mas que, por sua excepcional lucratividade, comportava tranquilamente a remuneração deste custo e ainda assim produzir elevada rentabilidade, como adiante se verá. Há, porém, o outro lado da moeda. Os direitos de entrada e saída das alfândegas do império e outras formas de exação apropriadas pela máquina fiscal do Reino, até aqui contabilizados como custos nos meus próprios cálculos, devem ser relativizados, pois, de alguma forma, uma parcela substancial desses mesmos recursos acaparados pelo Estado retornava aos bolsos dos próprios comerciantes, recompondo sua lucratividade, beneficiados que eram indiretamente pelos recursos públicos aplicados pelo governo na segurança do próprio empreendimento mercantil. Ou ainda quando, por via de contratos e privatizaçôes, transferia direitos de propriedade, inclusive de inestimáveis bens públicos, como se verificou no repasse de manufaturas reais a particulares, negociantes de grosso trato previamente instalados na administração dos empreendimentos.

\section{Afinal, havia superlucros ou não?}

Como já se demonstrou, através do método estatístico de regressão linear, ${ }^{19}$ os produtos ditos de baixa lucratividade alcançavam 20\% de sobrepreço, caso do melaço (21,5\%), produto que, por sua secular comercialização, constitui-se em evidência insofismável de sua viabilidade econômica neste patamar de lucratividade. Ou, dito de outra forma, 20\%, nos termos da minha mensuração — por Villela considerada precária —, foram suficientes para manter a atividade econômica que lhe corresponde por um longo tempo.

Numa escala intermediária alojam-se os produtos por nós classificados como de média lucratividade, cujos índices de preço variam entre $40 \%$ e $70 \%$, dentre os quais se notabilizam importantes produtos da exportaçáo colonial, a começar pelo açúcar branco $(41,70 \%)$ que hegemonizou a pauta de exportação em sua longa duração secular. Todas as variedades de couros (média de 53,8\%); e o algodão, com $64,5 \%$, produto rei na fase final da colônia. Mesmo que desses índices de lucratividade tivéssemos que abater os custos suplementares requeridos por Villela, ainda assim seriam considerados como produtos de excelente lucratividade.

Os baixíssimos índices de rentabilidade da Companhia das Índias Orientais holandesas nos negócios coloniais estimados entre 3,3\% e 7,9\%, obtidos pelo cálculo da diferença entre os dividendos distribuídos aos acionistas e o preço médio das suas açôes na Bolsa, ${ }^{20}$ utilizados por nosso crítico como referencial para contestar os superlucros, náo podem ser tomados

\footnotetext{
${ }^{19}$ ARRUDA, José Jobson de Andrade, op. cit., p. 566-567.

${ }^{20}$ VILLELA, André Arruda, op. cit., p. 8. Completada pela nota 33. 
como parâmetro para avaliar o desempenho da economia colonial portuguesa por expressarem uma realidade econômica totalmente diversa. Não é apenas a rentabilidade líquida que conta na lucratividade geral produzida pelas Companhias holandesas. Contam os benefícios indiretos. As taxas impostas pelo Estado aos negociantes para conceder e renovar cartas de monopólio, licenças, passaportes e, até mesmo, propinas para que projetos contrários aos seus interesses fossem abandonados pelo Estado. Enorme pressão exercida sobre a riqueza dos mercadores, não raramente compungidos a investir capitais no financiamento das políticas de Estado, especialmente das possíveis campanhas militares que poderiam redundar em calotes espetaculares, uma forma indireta de expropriaçáo do capital mercantil e, ao mesmo tempo, uma prova robusta da alta rentabilidade dos empreendimentos mercantis.

Mas o que interessa objetivamente, no caso, são os números que expressam a lucratividade do comércio colonial. Os índices esgrimidos por André Vilella, com suporte em Jan de Vries, não são, por exemplo, endossados por Oscar Gelderblom. ${ }^{21} \mathrm{O}$ fundamental é reter, a partir deste autor, os huge profits auferidos pelas primeiras companhias holandesas operando na Ásia. Entre os anos de 1598 e 1608 os comerciantes aventureiros de Amsterdã tiveram retornos anuais médios de 27,4\%. Os retornos líquidos somaram nove milhôes de guilders em 1608, duas vezes e meia o capital subscrito para a câmara de comércio de Amsterdã para a VOC em 1602.

Para contornar o problema oriundo do dilatado tempo da operaçáo ditado pela demora das viagens - que imobilizavam capitais e tardavam a produzir liquidez destinada ao reinvestimento nas viagens subsequentes —, foi criado um mercado monetário em Amsterdá na forma engenhosa de uma operação financeira que viabilizava a alavancagem de recursos, por parte dos grandes investidores, que vendiam participação nos lucros a quem preferisse receber $8 \%$ de retorno seguro sobre o capital investido, em vez de correr o "alto risco dos investimentos no comércio asiático". 22 Porcentual de remuneração acima da média apontada por André Villela, em torno de 5\%, e que correspondia à parte menor da lucratividade obtida na operaçáo, pois, certamente, o ganho dos investidores que se dispunham a correr o risco do empreendimento era muito mais elevado do que $8 \%$. Mecanismo financeiro este que ampliava substancialmente a liquidez para reinvestimentos continuamente aprimorados, como se constata na decisão tomada pela VOC de permitir aos acionistas o pagamento de suas cotas-partes em quatro chamadas anuais sucessivas, tempo suficiente para que os dividendos das viagens anteriores gerassem os recursos de capital necessários à continuidade das operaçóes. O resultado deste aprimoramento foi o surgimento de um mercado secundário para as ações da VOC, inflacionando de tal modo o mercado de capitais que as taxas de ju-

\footnotetext{
${ }^{21}$ GELDERBLOM, Oscar. The Organization of Long-Distance Trade in England and the Dutch Republic, 1550-1650. In: GELDERBLOM, Oscar (Ed.). The Political Economy of the Dutch Republic. Surrey: Ashgate, 2009. p. 240.

22 Ibid, p. 238.
} 
ros pagas no mercado financeiro baixaram de $8 \%$ para $4 \%$ entre 1590 e $1650,{ }^{23}$ reduzindo-se o lucro dos cotistas financistas, mas elevando os ganhos dos cotistas investidores.

$\mathrm{Na}$ categoria alta lucratividade situam-se as mercadorias cujos lucros estavam acima de $70 \%$. Produtos, em sua grande maioria, incluídos no processo de diversificação agropastoril iniciado por volta de 1780 e que se prolonga até 1830 . A saber, café $(84,68 \%)$, arroz $(101,29 \%)$ e produtos com presença secular no trânsito comercial: cacau $(99,7 \%)$ e tabaco (103,74\%). Isso para não falar de lucratividades excepcionais, cujo exemplo emblemático é o pau-brasil, que alcançava fantásticos $778,71 \%$, certamente por ser um contrato exclusivo obtido junto ao poder Real.

Que tipo de conclusão se pode aferir destes números à luz das observações críticas interpostas?

Se as baixas lucratividades não sustentam a tese dos superlucros, o mesmo não se pode dizer das lucratividades médias, certamente capazes de remunerar os custos explicitamente registrados nas Balanças do Comércio, relacionados no ensaio estatístico de Adrian Balbi, e todos os demais que a imaginação de nosso crítico possa elencar e que as futuras pesquisas possam vir a consignar, e, assim mesmo, produzir lucros satisfatórios, isto é, capazes de manter a máquina mercantil em movimento.

O que não dizer então dos produtos com lucratividade entre $80 \%$ e 100\%? Até mesmo neste patamar nosso crítico rejeita a ideia de superlucro! Em que outra experiência histórica conhecida nos tempos da colonização moderna índices semelhantes foram comprovados?

A parte que me coube propriamente no ensaio crítico de André Villela refere-se ao questionamento sobre a existência de "superlucros" nas operações mercantis entre a metrópole e a colônia. Eixo de resto central na problemática colonial brasileira, porque expressa concretamente a prática monopolista e a criação de recursos que poderiam alimentar a industrialização inglesa. Com um desdobramento a mais, não contemplado na crítica em apreço. Referimo-nos à criação de condiçôes para o desenvolvimento das manufaturas portuguesas e o concomitante avanço da indústria têxtil francesa. Isto porque não pensamos a Revolução Industrial como evento unívoco, próprio do gênio britânico, como se a sociedade inglesa fosse o homo sapiens da industrialização. Preferimos conceber a Revolução Industrial como uma época, a época da Revolução Industrial, que incluiria França e Portugal, e, por vias travessas o Brasil por se tornar, numa conjuntura propícia, o elemento estratégico daquelas transformaçôes pelo controle da matéria-prima decisiva naquele momento: o algodão. ${ }^{24}$

De uma forma mais ampla, pensando historiograficamente, a questão posta por Villela não é nova. Trata-se de uma reciclagem. Remonta a Adam Smith. Nos anos 1960 foi retomada no famoso debate entre Richard Sheridan e Paul Thomas. ${ }^{25}$ Sheridan demonstrou a

\footnotetext{
${ }^{23}$ Ibid, p. 239.

${ }^{24}$ ARRUDA, José Jobson de Andrade. Uma colônia entre dois impérios. Bauru: Edusc, 2008.

${ }^{25}$ Cf. SHERIDAN, Richard B. The Wealth of Jamaica in the Eighteenth century. Economic History Review, v. XVIII, p. 292-311, 1965; THOMAS, Robert Paul. The Sugar colonies of the Old Empire: Profit or Loss for Great Britain? Economic History Review, v. XXI, n. 1, p. 30-45, 1968.
} 
estreita relação entre o crescimento econômico da Inglaterra e os volumosos recursos provenientes das colônias antilhanas, especialmente da Jamaica, que teriam produzido apenas no ano de 1773 recursos da ordem de 1,5 milhão de libras. ${ }^{26}$ Relação negada por Thomas, sob o argumento de que os investimentos realizados nas colônias foram improdutivos por retardarem o desenvolvimento econômico da Inglaterra. ${ }^{27}$ Argumentos que se renovam, pró e contra, nas décadas seguintes, quando Philip Coelho, ${ }^{28}$ nas pegadas de Thomas, concluiu que os verdadeiros ganhadores nas Índias Ocidentais britânicas foram os proprietários das plantations, que se valeram dos preços mais altos no mercado britânico do que aqueles praticados no mercado internacional, além de se beneficiaram do escudo militar do império britânico. Por outras vias, Michel Morineau contra-argumenta, apontando o lucro do comércio inglês em relação a Portugal que, apenas no ano de 1760, produziu 1.309.909 libras, ${ }^{29}$ recursos estes que, sabidamente, não eram gerados internamente no reino português, eram frutos da extração de excedentes coloniais, sobejamente da colônia brasílica.

Se há muitos historiadores de renome, com os quais Vilella se identificaria, contrários às teses originais de Sheridan, tais como Ralph Davies, M. W. Flinn, e outros mais que ele mesmo invoca, como Paul Bairoch, defensores do crescimento agregado da renda nacional, há também, no sentido contrário, especialistas na temática da Revolução Industrial que não perfilham ao lado de suas teses, a exemplo de Peter Mathias, W. E. Minchinton, P. Deane e W. A. Cole. Renomados historiadores que afirmam serem os mercados ultramarinos consumidores de manufaturas inglesas, fornecedores de matérias-primas industriais e alimentos, condiçôes estratégicas do processo de industrialização em todos os seus estágios, pois o comércio externo amplificou a poupança interna, capital decisivo para o aceleramento econômico alavancado na última década do século XVIII e altamente concentrado nas indústrias que tinham custos decrescentes e mercados mais elásticos. Enquanto a renda real britânica cresceu 44\% entre 1700 e 1770, a produção das indústrias conectadas aos mercados externos cresceu $156 \%$, e as destinadas ao mercado interno, apenas $14 \%$. Ao mesmo tempo, o perfil das exportaçôes mudava substancialmente. Deslocava-se da Europa para as colônias. Entre 1701 e 1790 as exportaçóes para a Europa recuaram $15 \%$, passando de $72 \%$ no quinquênio 1701-1705 para 57\% no quinquênio 1786-1790. Reversamente, as exportaçóes direcionadas à América passaram de 6\% para 25\%; para a África de 4\% para 13\%; para a Ásia de 4\% para $12 \%{ }^{30}$ Demonstração inequívoca de que o mundo das colônias disperso por três continentes - América, África e Ásia —, que consumia apenas 15\% de todas as exportaçóes ingle-

\footnotetext{
${ }^{26}$ SHERIDAN, Richard B., ibid, p. 182.

${ }^{27}$ THOMAS, Robert Paul, ibid, p. 30.

${ }^{28}$ COELHO, Philip R. P. The Profitability of Imperialism: the British Experience in the West Indies 17681772. Explorations in Economic History, v. 10, n. 3, p. 153-280, 1973.

${ }^{29}$ MORINEAU, Michel. Incroyables Gazettes et Fabuleux Métaux. Paris: Editions de la Maison des Sciences de l'Homme, 1985. p. 182.

${ }^{30}$ Cf. MITCHELL, Brian; DEANE, Phyllis (Col.). Abstract of British Historical Statistics. Cambridge: Cambridge University Press, 1971. p. 274-337.
} 
sas nos inícios do século XVIII, passou a 42\% no final do mesmo. Sendo que o salto mais expressivo da procura colonial por mercadorias britânicas deu-se no período 1771-1790, exatamente o momento em que, na opinião da grande maioria dos especialistas na temática, dispara a industrialização inglesa. ${ }^{31}$

Nesse passo, a tese de Joseph Inikori sobre a importância do mercado atlântico no deslanchar da Revolução Industrial inglesa torna-se extremamente relevante. ${ }^{32} \mathrm{O}$ que importa, nos seus termos, é saber em que momento a industrialização baseada na indústria doméstica preexistente atinge seu limite e as inovaçôes tecnológicas decorrentes devem ser atribuídas aos influxos do mercado externo. Não somente pelo consumo das manufaturas produzidas, mas também pelo fornecimento de matérias-primas estratégicas a custos decrescentes. Caso do algodão, que por esta via rebaixou substancialmente o custo de produção do setor têxtil britânico, contribuição tão importante quanto as novas tecnologias ou formas organizacionais da produção introduzidas no processo. Nestes termos, o comércio internacional tornou-se uma condição decisiva na transformação em curso, avultando o papel do mercado atlântico, elevado à condição de centro dinâmico do fluxo internacional de mercadorias naquele momento. $\mathrm{O}$ valor monetário transacionado entre os parceiros que operavam na área passou de 1.286 milhão de libras esterlinas por ano, entre 1501-1550, para 7.970 entre 16511670, e 21.903 no período 1761-1780. Sendo necessário considerar, além disso, que todo comércio da Europa Ocidental com a Ásia nos séculos XVII e XVIII dependia do fluxo de metais americanos que pagavam as importaçóes europeias, mercadorias estas que, por sua vez, destinavam-se à reexportação no mundo atlântico, mecanismo que se repetia, em larga medida, no comércio intraeuropeu, onde circulavam mercadorias de origem colonial, pagas com recursos monetários igualmente coloniais. Inquestionável o fato de que nos momentos cruciais do processo de transformação da indústria inglesa, em torno dos anos 1780, as manufaturas inglesas destinadas à África Ocidental e às Américas representavam 60\% do incremento na produção britânica de manufaturados destinados ao ultramar. Números globais que, se setorizados, tornam-se ainda mais expressivos, pois estimulavam o crescimento das indústrias de exportação tradicionais (lã e linho), mas, sobretudo, das novas indústrias do algodão e dos metais. ${ }^{33}$

André Villela admite que "após a Revolução Industrial o comércio exterior passou a ser decisivo para a economia europeia”. ${ }^{34}$ Não. É um processo enraizado na expansão comercial

\footnotetext{
${ }^{31}$ Particularmente entendemos que 1780 é o ano marco da grande transformação, quando se enredam dinâmica mercantil e transformação industrial. Cf. ARRUDA, José Jobson de Andrade. A grande revolução inglesa, 1640-1780. São Paulo: Hucitec, 1996. Especialmente p. 134 e ss.

${ }^{32}$ INIKORI, Joseph E. Africans and the Industrial Revolution in England. Cambridge: Cambridge University Press, 2002.

${ }^{33}$ Ibid, p. 476-482. Dados numéricos reproduzidos em INIKORI, Joseph E. Atlantic Markets and Technological Development in England During the Industrial Revolution, 1750-1850. Texto apresentado no 6o Congresso Brasileiro de História Econômica, Conservatória, setembro de 2005, especialmente p. 15.

${ }^{34}$ VILLELA, André Arruda, op. cit., p. 15.
} 
e marítima do século XVI, que se acelera na segunda metade do século XVIII e tem continuidade no século XIX em termos muito mais competitivos do que fora no século anterior por conta das rivalidades entre as naçôes industrializadas ou em vias de fazê-lo, os first and late comers. A constituição de um mercado com feiçôes mundiais controlado pelos ingleses, em função de sua poderosa Royal Navy erigida no bojo da Revolução Inglesa, deu-lhes a vantagem estratégica decisiva que levou à passagem da manufatura à maquinofatura, o mercado no comando da produção. No século XIX, inverte-se. A força relativa do comércio internacional arrefece, pois o comando das transformaçóes transfere-se para o setor produtivo, alavancado pelo capital financeiro. ${ }^{35}$

As opiniôes sobre o papel das colônias não dividem apenas historiadores ou economistas especialistas na matéria. Dividem a própria trajetória intelectual de reputados historiadores do porte de David Landes, reconvertidos em suas convicçóes. Se hoje se identifica com a linhagem interpretativa defendida por Vilella, pois em 1998 afirmava sem rebuços que "as mudanças cruciais [na Revolução Industrial] eram largamente independentes do sistema atlântico", ${ }^{36}$ não foi sempre assim. Landes passou visivelmente por uma reconversão em suas convicçóes mais enraizadas, exemplo de sua inexplicável defesa do imperialismo japonês na Ásia que, de prática abominável, passou a ser uma "boa escola". ${ }^{37}$ Encaixa-se no revisionismo que marcou o XII Congresso Internacional de História Econômica realizado em Madri, exatamente no ano de 1998, centrado na temática dos impérios cujo título era por si só uma antecipação de suas conclusôes: The costs and benefits of European imperialism from the conquest of Ceuta, 1415, to the treaty of Lusaka, $1974 .{ }^{38}$ Uma catilinária orquestrada contra a tese da exploração colonial e seu contributo para a industrialização, liderada por Patrikc O'Brien e Leandro Prados de la Escosura, contando com a adesão de nossos confrades portugueses Jorge Pedreira e Pedro Lains. Um Landes muito diferente do autor de Unbound Prometheus, de 1968, e até mesmo do historiador festejado com o qual compartilhei a sessão Oceanic Trade, Colonial Wares and Industrial Revolution, realizada em Milão, em 1994, organizada por Maxine Berg exatamente para contestar os ataques de N. Crafts à concepçáo colonialista da Revolução Industrial. Em Unbound Prometheus Landes fora enfático:

Mais duradoura e mais estimulante para o desenvolvimento econômico europeu foi a exploraçấo sistemática dos territórios coloniais (...) A importância dessas colônias para o desenvolvimento econômico europeu está em que elas produziram um volume cada vez maior de artigos de

\footnotetext{
${ }^{35}$ Cf. ARRUDA, José Jobson de Andrade. A grande revolução inglesa 1640-1780. São Paulo: Hucitec, 1996; . Uma colônia entre dois impérios. Bauru: Edusc, 2008. Especialmente p. 170-180.

${ }^{36}$ LANDES, David. A riqueza e a pobreza das naçôes. Rio de Janeiro: Campus, 1998. p. 133.

${ }^{37}$ Ibid, p. 494.

${ }^{38}$ O’BRIEN, Patrick K.; ESCOSURA, Leandro Prados de la (Eds.). The Costs and Benefits of European Imperialism from the Conquest of Ceuta, 1415, to the Treaty of Lusaka, 1974. Revista de Historia Económica, ano XVI, n. 1, invierno 1998.
} 
exportação, primordialmente gêneros alimentícios e matérias-primas, e receberam, em contrapartida, um fluxo crescente de produtos manufaturados europeus. Esse não foi um lucro momentâneo. Constituiu um incremento duradouro para a pressão de demanda sobre a indústria europeia e, desse modo, como veremos, contribuiu para a Revolução Industrial. ${ }^{39}$

A pergunta que não quer calar é: por que Landes mudou? ${ }^{20}$

Diante das evidências numéricas e do repasse bibliográfico em tela, é possível recusar peremptoriamente o papel das colônias no arranque industrial dos países centrais, Inglaterra à frente? É inegável que o mundo colonial teve um papel decisivo neste cenário, promovendo a transferência de riquezas das colônias para as metrópoles. No caso de Portugal, o excedente sob a forma de remessas líquidas ou créditos consignados na balança comercial sustentou os tesouros públicos, alimentou a formação da dívida pública, abasteceu os cofres dos particulares envolvidos da rede mercantil operando nas águas e territórios do império, além de ter se transformado num mercado consumidor seguro para as manufaturas portuguesas.

Discordâncias à parte, sou grato a André Villela pela oportunidade de retornar a este tema instigado pelo teor crítico, incisivo, mas respeitoso de seus questionamentos.

\section{Referências bibliográficas}

ARRUDA, José Jobson de Andrade. A Grande Revolução Inglesa 1640-1780. São Paulo: Hucitec, 1996.

. Comércio colonial e exclusivo metropolitano. In: SZMRECSÁNYI, Tamás (Org.). História Econômica do Período Colonial. São Paulo: Hucitec, 1996. p. 220.

. David Landes, um historiador desacorrentado. Revista Economia e Sociedade, Campinas, n. 12, p. 87-108, 1999.

- Decadência ou crise do império luso-brasileiro: o novo padrão de colonização do século XVIII. Revista USP, São Paulo, p. 66-79, jun./ago. 2000.

- O Brasil no Comércio Colonial. São Paulo: Ática, 1980.

- Uma Colônia entre dois Impérios. Bauru: Edusc, 2008.

BALBI, Adriano. Essai statistique sur Le royaume de Portugal et l'Algarve, comparé aux autres Etats de l'Europe. Paris: Chez Rey et Gravier, 1822.

BRAUDEL, Fernand. Civilização material, economia e capitalismo. São Paulo: Martins Fontes, 1966. v. 2.

\footnotetext{
${ }^{39}$ LANDES, David. Prometeu desacorrentado. Rio de Janeiro: Nova Fronteira, 1994 (1. ed. Cambridge University Press, 1969. p. 42-43).

${ }^{40}$ Cf. ARRUDA, José Jobson de Andrade. David Landes, um historiador desacorrentado. Revista Economia e Sociedade, Campinas, n. 12, p. 87-108, 1999.
} 
COELHO, Philip R. P. The Profitability of Imperialism: the British Experience in the West Indies 1768-1772. Explorations in Economic History, v. 10, n. 3, p. 153-280, 1973.

GELDERBLOM, Oscar. The Organization of Long-Distance Trade in England and the Dutch Republic, 1550-1650. In: GELDERBLOM, Oscar (Ed.). The Political Economy of the Dutch Republic. Surrey: Ashgate, 2009.

INIKORI, Joseph E. Africans and the Industrial Revolution in England. Cambridge: Cambridge University Press, 2002.

. Atlantic Markets and Technological Development in England During the Industrial Revolution, 1750-1850. Texto apresentado no 6o Congresso Brasileiro de História Econômica, Conservatória, setembro de 2005.

LANDES, David. A riqueza e a pobreza das naçôes. Rio de Janeiro: Campus, 1998. . Prometeu desacorrentado. Rio de Janeiro: Nova Fronteira, 1994 (1. ed. Cambridge University Press, 1969).

MITCHELL, Brian; DEANE, Phyllis (Col.). Abstract of British Historical Statistics. Cambridge: Cambridge University Press, 1971.

MORINEAU, Michel. Incroyables Gazettes et Fabuleux Métaux. Paris: Editions de la Maison des Sciences de l'Homme, 1985.

O'BRIEN, Patrick K.; ESCOSURA, Leandro Prados de la (Eds.). The Costs and Benefits of European Imperialism from the Conquest of Ceuta, 1415, to the Treaty of Lusaka, 1974. Revista de Historia Económica, ano XVI, n. 1, invierno 1998.

SHERIDAN, Richard B. The Wealth of Jamaica in the Eighteenth Century. Economic History Review, v. XVIII, p. 292-311, 1965.

THOMAS, Robert Paul. The Sugar Colonies of the Old Empire: Profit or Loss for Great Britain? Economic History Review, v. XXI, n. 1, p. 30-45, 1968.

VILLELA, André Arruda. Exclusivo metropolitano, superlucros e acumulação primitiva na Europa pré-industrial. Topoi, v. 12, n. 23, p. 4-29, jul./dez. 2011. 